\title{
Fractone Bulbs Derive from Ependymal Cells and Their Laminin Composition Influence the Stem Cell Niche in the Subventricular Zone
}

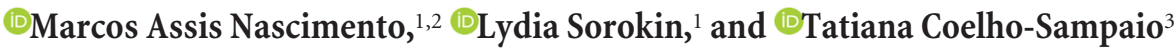 \\ ${ }^{1}$ Institute of Physiological Chemistry and Pathobiochemistry and Cells-in-Motion (CiM) Cluster of Excellence, University of Münster, 48149 Münster,

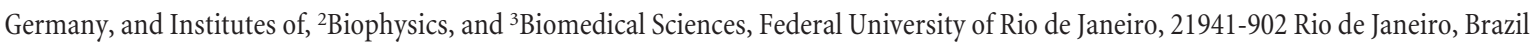

Fractones are extracellular matrix structures in the neural stem cell niche of the subventricular zone (SVZ), where they appear as round deposits named bulbs or thin branching lines called stems. Their cellular origin and what determines their localization at this site is poorly studied, and it remains unclear whether they influence neural stem and progenitor cell formation, proliferation, and/or maintenance. To address these questions, we analyzed whole-mount preparations of the lateral ventricle of male and female mice by confocal microscopy using different extracellular matrix and cell markers. We found that bulbs are rarely connected to stems and that they contain laminin $\alpha 5$ and $\alpha 2$ chains, respectively. Fractone bulbs were profusely distributed throughout the SVZ and appeared associated with the center of pinwheels, a critical site for adult neurogenesis. We demonstrate that bulbs appear at the apical membrane of ependymal cells at the end of the first week after birth. The use of transgenic mice lacking laminin $\alpha 5$ gene expression (Lama5) in endothelium and in FoxJ1expressing ependymal cells revealed ependymal cells as the source of laminin $\alpha 5$-containing fractone bulbs. Deletion of laminin $\alpha 5$ from ependymal cells correlated with a $60 \%$ increase in cell proliferation, as determined by phospho-histone $\mathrm{H} 3$ staining, and with a selective reduction in the number of slow-dividing cells. These results indicate that fractones are a key component of the SVZ and suggest that laminin $\alpha 5$ modulates the physiology of the neural stem cell niche.

Key words: ependymal cell; fractone; laminin; neural stem cell; stem cell niche; subventricular zone

\section{Significance Statement}

Our work unveils key aspects of fractones, extracellular matrix structures that are present in the SVZ that still lack a comprehensive characterization. We show that fractones extensively interact with neural stem cells, whereas some of them are located precisely at pinwheel centers, which are hotspots for adult neurogenesis. Our results also demonstrate that fractones increase in size during aging and that their interactions with neural stem and progenitor cells become more complex in old mice. Last, we show that fractone bulbs are produced by ependymal cells and that their laminin content regulates neural stem cells.

\section{Introduction}

The subventricular zone (SVZ) is the largest and most studied neural stem cell (NSC) niche in adult mice. Within this niche,

\footnotetext{
Received 0ct. 24, 2017; revised Feb. 12, 2018; accepted Feb. 24, 2018.

Author contributions: M.A.N. designed research; M.A.N. performed research; L.S. contributed unpublished reagents/analytic tools; M.A.N. analyzed data; M.A.N., L.S., and T.C.-S. wrote the paper.

This work was supported by the Cells-in-Motion Cluster of Excellence (Grant EXC1003) from the German Research Foundation, Brasilien-Zentrum of Westfälische Wilhelms-Universität Münster/Deutscher Akademischer Austauschdienst, and the National Council for Scientific and Technological Development (Grant 238147/2012-6). We thank Dr. Eva Korpos for discussion, Dr. Bhavin Shah for help with whole mounts, and Stefan Luetke Enking for technical assistance. Fox J1-Cre mice were a gift from Dr. Martin Bähler.

The authors declare no competing financial interests.

Correspondence should be addressed to Marcos Assis Nascimento, Avenida Carlos Chagas Filho 373, Centro de Ciências da Saúde, B-11, 21941-902 Rio de Janeiro, Brazil. E-mail: manascimento@biof.ufrj.br.

DOI:10.1523/JNEUROSCI.3064-17.2018

Copyright $\odot 2018$ the authors $\quad 0270-6474 / 18 / 383880-10 \$ 15.00 / 0$
}

neural stem and progenitor cells (NSPCs) contact the ependymal cell layer lining the ventricles (Doetsch et al., 1999) and the basement membranes (BMs) of blood vessels (Shen et al., 2008; Tavazoie et al., 2008). BMs are specialized extracellular matrix (ECM) sheets, which in most tissues underlie endothelia and epithelial layers and ensheath nerves and muscle fibers. In the CNS, blood vessels are surrounded by two biochemically distinct BMs, one underlying the endothelium and one deposited by astrocytes (Sixt et al., 2001; Wu et al., 2009). Apart from the BMs of blood vessels and those lining the pial surface the only other type of BMs within the brain parenchyma are the fractones, an atypical fractallike structure present in the SVZ (Leonhardt and Desaga, 1975; Mercier et al., 2002, 2011). Fractones are described to emerge from capillaries as thin stems, which branch profusely as they approach the ventricular surface. A second component of these atypical 
BMs appears at the ependymal layer as small spherical deposits, which were called bulbs. Due to their location, bulbs were assumed to correspond to the bulging terminations of each individual stem, although a physical connection between stems and bulbs has not yet been demonstrated. Laminins are the main functional constituents of BMs, acting as a molecular scaffold for its assembly and providing biological signals that control cell migration, differentiation, and proliferation (Smyth et al., 1999). All members of the laminin family are heterotrimers composed of one $\alpha$, one $\beta$, and one $\gamma$ chain that combine to form 16 distinct isoforms with tissue-specific distributions and functions (Durbeej, 2010). The $\mathrm{C}$ terminus of the 5 laminin $\alpha$ chains are key to laminin signaling, bearing in most isoforms the domains recognized by membrane receptors that regulate cellular adhesion, migration, and division (Colognato and Yurchenco, 2000). Laminins containing the $\alpha 5$ chain have been shown to be crucial for pluripotent stem cell survival and self-renewal in vitro (Hongisto et al., 2012; Miyazaki et al., 2012; Laperle et al., 2015) and for inhibiting the proliferation in vivo (Wegner et al., 2016). The effects of fractones on the physiology of NSPCs has been attributed to the perlecan; however, this is based solely on its ability to bind growth factors (e.g., bFGF, BMP-4, and BMP-7) and to present them to contacting cells (Douet et al., 2012; Kerever et al., 2014; Mercier and Douet, 2014).

Despite growing evidence of the relevance of fractones in the SVZ (Kazanis et al., 2010; Mercier et al., 2012), a comprehensive understanding of their location is still lacking, in particular how fractones relate to NSPCs and pinwheels, which are critical structures for adult neurogenesis formed by NSPCs and ependymal cells at the ventricle wall (Mirzadeh et al., 2008). In addition, identifying the cells responsible for producing fractones and determining whether the laminin composition plays a role in SVZ physiology are crucial to understanding how stem cells are formed and maintained at this site.

Previous studies have identified interactions between GFAP $^{+}$ neural stem cells and pan-laminin ${ }^{+}$fractones using electron microscopy and immunofluorescence staining of coronal sections of the SVZ (Leonhardt and Desaga, 1975; Mercier et al., 2002, 2011). Although suitable for unveiling the existence of such interactions, analyses of thin tissue sections cannot fully address interactions between fractones and neural stem cells at the SVZ because of the filamentous nature of $\mathrm{GFAP}^{+}$cells. We therefore here analyze the position of fractone bulbs using $3 \mathrm{D}$ reconstruction of immunofluorescently stained whole mounts of the lateral wall, revealing that bulbs are frequently located precisely at the center of pinwheels. To identify the cell responsible for producing fractone bulbs and to investigate whether its laminin composition is important for regulating NSPC proliferation in the SVZ, we analyzed mice lacking Lama5 expression in endothelial cells or ciliated ependymal cells. Our data indicate that ependymal cells are the source of laminin $\alpha 5$-containing fractones, and demonstrated that the loss of laminin $\alpha 5$ at this site correlated with a $60 \%$ increase in overall proliferation of NSPCs and to a decrease in the number of slow-dividing cells. Our findings indicate that fractone bulbs are ependymally derived basement membrane structures critical to SVZ physiology.

\section{Materials and Methods}

Experimental animals. FoxJ1-Cre::Lama5 ${ }^{-1-}$ mice were obtained by crossing FoxJ1-Cre mice (Zhang et al., 2007) with Lama5 flox/flox mice (Song et al., 2013); Tek-Cre::Lama5 ${ }^{-1-}$ mice were obtained in an analogous way (Song et al., 2013). All mice were on a C57BL/6 background (Charles River Laboratories). Male and female mice were used, and no visible differences between the two sexes were observed. Animal breeding and procedures were conducted according to the German Animal Welfare guidelines.

Histological preparations. Brains were dissected and fixed overnight at $4^{\circ} \mathrm{C}$ in $2 \%$ paraformaldehyde in PBS. Thick $(50 \mu \mathrm{m})$ coronal sections were made using a Zeiss Vibratome. Whole mounts were prepared from dissecting lateral walls of the lateral ventricles, as described previously (Mirzadeh et al., 2008, 2010).

Antibodies and immunofluorescence. Sections and whole mounts were washed in PBS, blocked with 5\% goat serum/PBS or 1\% BSA/PBS (SigmaAldrich), and incubated with primary antibodies overnight at $4^{\circ} \mathrm{C}$. The following primary antibodies were used: anti-laminin $\alpha 2$ (4H8-2; Schuler and Sorokin, 1995); anti-laminin $\alpha 5$ (4G6; Sorokin et al., 1997a); anti-laminin $\gamma 1$ (3E10; Sixt et al., 2001); anti-pan-laminin (455; Sorokin et al., 1990); anti- $\beta$-catenin (1:1000; catalog \#C2206, Sigma-Aldrich); anti-GFAP (1:800; catalog \#C9205, Sigma-Aldrich; 1:500; catalog \#539892, eBioscience); anti-nestin (1:100; catalog \#rat-401, Developmental Studies Hybridoma Bank at the University of Iowa); and anti-phosphohistone $\mathrm{H} 3$ (PH3; 1:500; catalog \#06-570, Millipore). After the incubation, tissues were thoroughly washed with PBS and incubated with the following secondary antibodies: Alexa Fluor 488 anti-rat (1:1000; catalog \#A11006, Life Technologies); Alexa Fluor 555 anti-rat (1:1000; catalog \#ab150154, Abcam); Alexa Fluor 568 anti-rabbit ( 1:1000; catalog \#A11011, Life Technologies); and Alexa Fluor 647 anti-rabbit ( 1:1000; catalog \#111605-144, Jackson ImmunoResearch/Dianova). After incubation with secondary antibodies, thick sections and whole mounts were mounted with mounting media and a coverslip. Tissues were analyzed using a Zeiss AxioImager Microscope equipped with epifluorescent optics and documented with a Hamamatsu ORCA ER camera or with an LSM 700 confocal laser-scanning microscope (Zeiss).

In situ hybridization. In situ hybridization for laminin $\alpha 5$ mRNA was performed as previously described (Sorokin et al., 1997b).

Pulse-chase assay for 5-ethynyl-2'-deoxyuridine. Three-month-old mice received intraperitoneal injections of $50 \mathrm{mg} / \mathrm{kg}$ 5-ethynyl-2'-deoxyuridine (EdU; Click-iT EdU Alexa Fluor 647 Imaging Kit; catalog \#c10340, Thermo Fisher Scientific) in sterile PBS at 3 consecutive days. Whole mounts of the ventricular lateral walls were prepared after 6 weeks and scanned in a Zeiss Axio Imager M2 with an automated stage, and EdUlabeled cells were counted using ImageJ software (National Institutes of Health, Bethesda, MD).

Morphological and statistical analyses. For $\mathrm{PH}^{+}{ }^{+}$nuclei quantification, whole mounts were photographed with a $10 \times$ objective lens in the Zeiss AxioImager Microscope. Pictures were merged using Photoshop CS3 (Adobe Systems). Merged pictures were processed using ImageJ, and nuclei were quantified. For quantification of the volume of fractone bulbs, pan-laminin staining in coronal sections was rendered in tridimensional volumes and quantified using Imaris version 7.0 software (Bitplane). For analyses of the interactions of $\mathrm{GFAP}^{+}$processes and bulbs in old mice, GFAP and pan-laminin staining of whole mounts was reconstructed in three dimensions using Imaris. Statistical analyses were made using GraphPad Prism 6 (GraphPad Software). A $t$ test with a 95\% confidence interval was used to analyze statistical differences in Figures $4 B, 5 B$, and $6, B$ and $C$.

\section{Results}

\section{An en face view of interactions between $\mathrm{GFAP}^{+}$cells and fractones}

To have a more comprehensive view of the interactions between NSCs and fractones, whole mounts of the SVZ were simultaneously immunofluorescently stained for laminin $\gamma 1$ to mark BMs, for GFAP to mark NSCs, and for $\beta$-catenin to delineate cell contacts at the ependymal layer. First, we observed that fractone bulbs are profusely distributed throughout the lateral wall of the lateral ventricle (Fig. 1A). Analysis of the occurrence of bulbs in coronal sections revealed that they also abound along the dorsal and medial walls of the lateral ventricle (Fig. $1 B$ ), as well as along the walls of the third and fourth ventricles (data not shown). En face view of the ventricular surface additionally revealed that frac- 

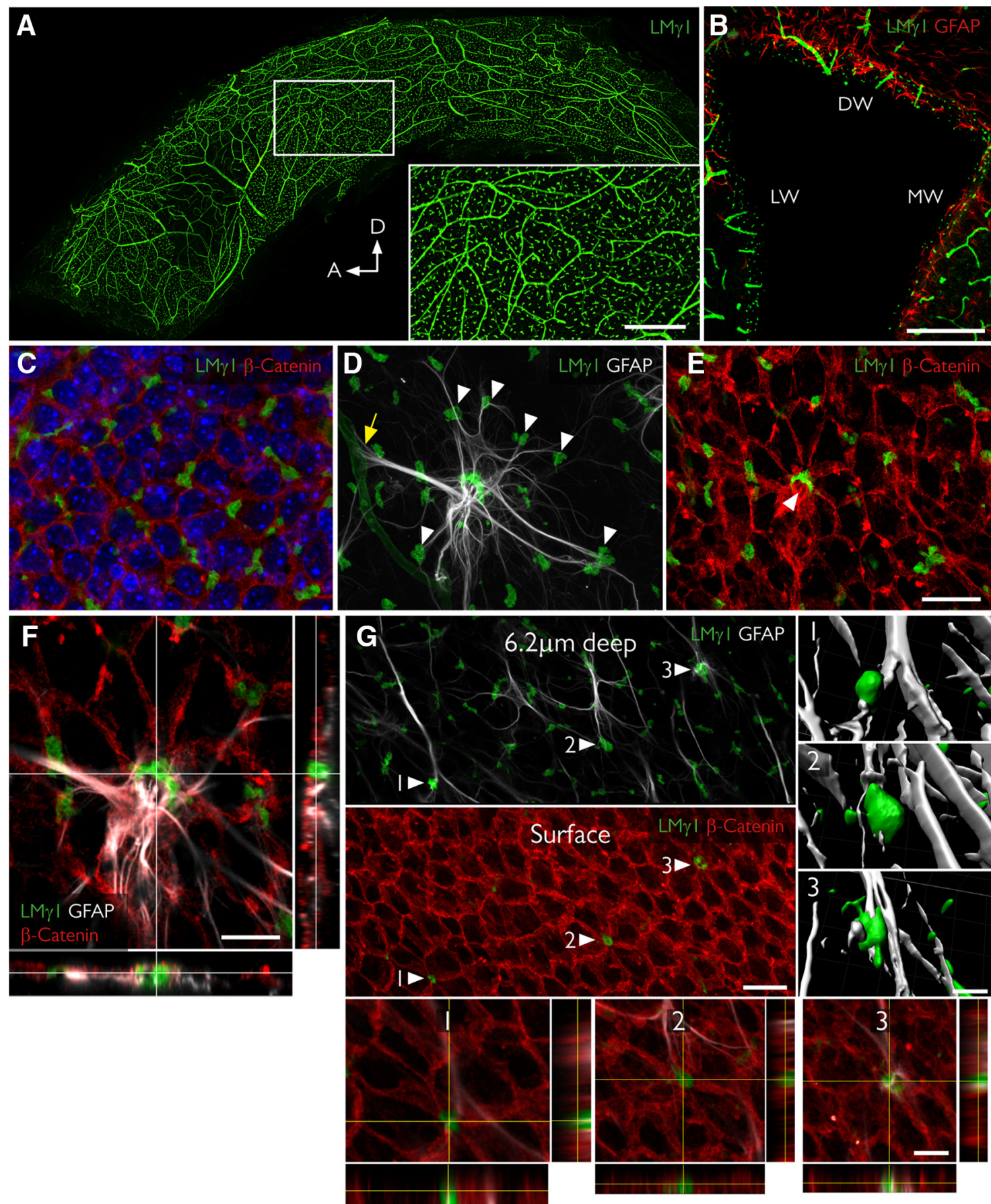

Figure 1. Fractones are a major BM source in the SVZ and appear at the center of pinwheels. $A$, Whole mount of the lateral wall of the lateral ventricle of an adult mouse immunofluorescently stained for laminin $\gamma 1$ (green). The frontal view reveals the profuse distribution of fractone bulbs. A higher magnification of the boxed area is depicted in the inset. $\boldsymbol{B}$, Coronal section through the lateral ventricle, showing the uniform distribution of laminin $\gamma 1^{+}$fractone bulbs (green) on all three walls: dorsal wall (DW), lateral wall (LW), and medial wall (MW). C, Frontal view of the ependymal cell layer, seen at $1 \mu \mathrm{m}$ depth relative to the ventricular surface, stained for laminin $\gamma 1$ (green) to visualize fractones and $\beta$-catenin (red) to visualize cell junctions in the ependymal layer.

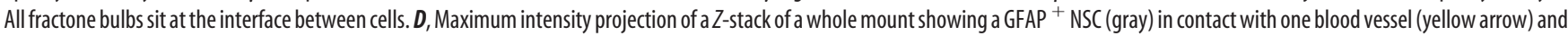
$>10$ fractone bulbs (arrowheads) at the same time. $\boldsymbol{E}$, The neural stem cell body also contacts a large bulb located at the center of a pinwheel (arrowhead). $\boldsymbol{F}$, Orthogonal views revealing that the NSC-fractone interaction seen in $\boldsymbol{C}$ and $\boldsymbol{D}$ occurs at the surface of a pinwheel center. G, GFAP ${ }^{+}$processes contact more bulbs at pinwheel centers (arrowheads) than bulbs at the basolateral surface of ependymal cells. Interactions between GFAP ${ }^{+}$processes and fractone bulbs were labeled 1-3 and rendered, revealing that GFAP ${ }^{+}$processes establish direct and complex contacts with fractones. Orthogonal views of these interactions confirm that fractone bulbs sit between ependymal cells at pinwheel centers and that GFAP ${ }^{+}$processes directly contact them. Scale bars: $A, 500 \mu \mathrm{m} ; A$, inset, $200 \mu \mathrm{m} ; \boldsymbol{B}, 200 \mu \mathrm{m} ; \boldsymbol{C}-\boldsymbol{E}, 25 \mu \mathrm{m} ; \boldsymbol{F}, 12 \mu \mathrm{m} ; \boldsymbol{G}, 25 \mu \mathrm{m} ; \boldsymbol{G}, 1-3,12 \mu \mathrm{m}$.

tone bulbs are located preferentially at the interface between neighboring cells in the ependymal layer (Fig. 1C). $\mathrm{GFAP}^{+}$neural stem cells interact with BMs of blood vessels (Fig. 1D, yellow arrow), but their cell bodies and processes also contact several fractone bulbs at the same time (Fig. $1 D$, arrowheads).
NSCs exhibiting processes that contact the CSF are the basic neurogenic unit in the SVZ and, together with surrounding ependymal cells, form a distinct pinwheel-like arrangement (Mirzadeh et al., 2008). We observed that fractone bulbs are frequently located at the center of pinwheels, coinciding with $\mathrm{GFAP}^{+}$hubs from 

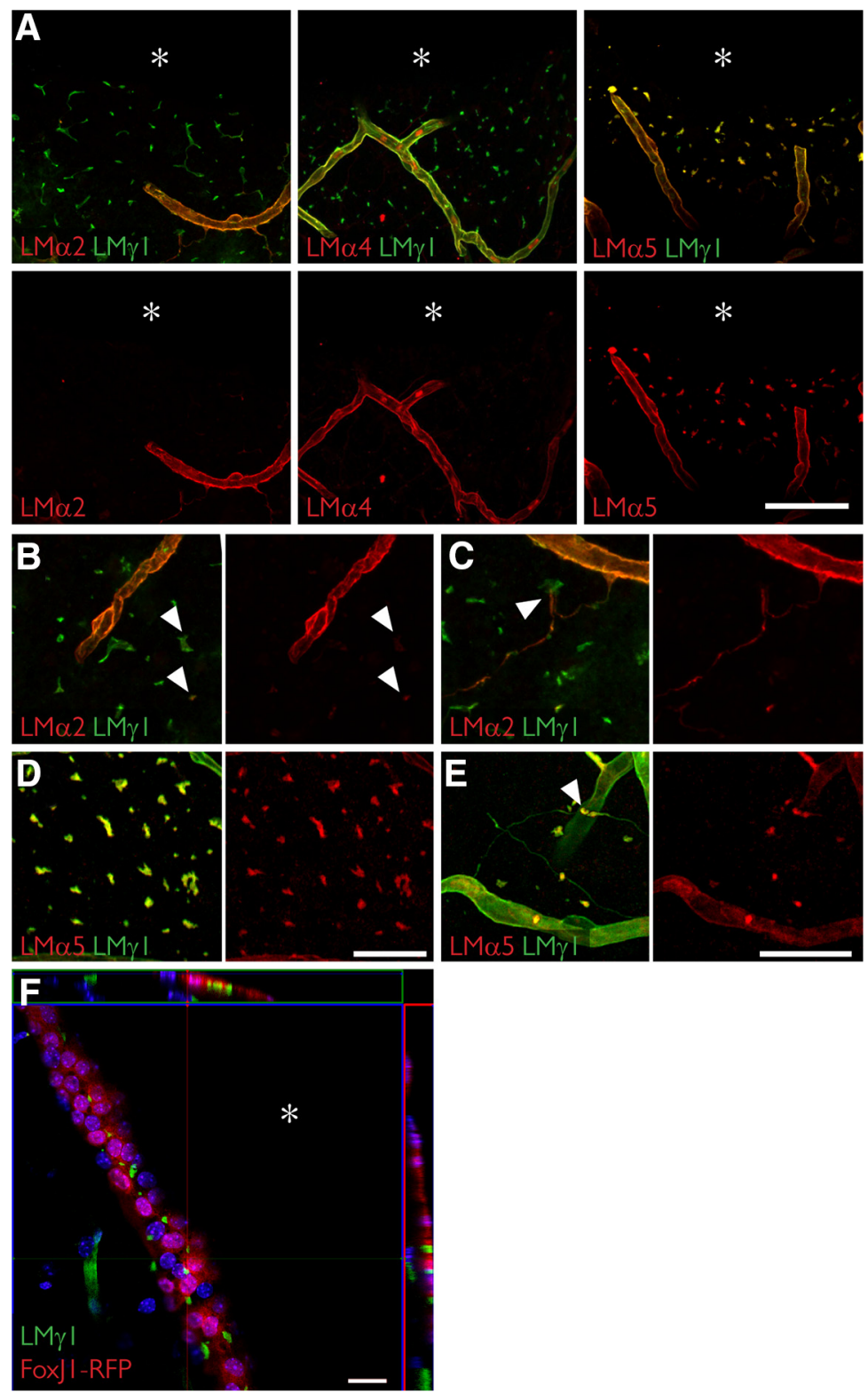

Figure 2. Fractone bulbs and fractone stems have distinct laminin compositions. A, Immunolabeling for laminin $\alpha 2$ (red, left), laminin $\alpha 4$ (red, middle), laminin $\alpha 5$ (red, right), and laminin $\gamma 1$ (green) seen in maximum-intensity projections of thick $(60 \mu \mathrm{m})$ coronal sections of young adult mice showing that fractone bulbs and blood vessels have distinct laminin compositions. Laminin $\alpha 5$ is the main $\alpha$ chain in fractone bulbs, followed by a faint presence of laminin $\alpha 2$. Laminin $\alpha 4$ is absent from fractones. $B$, Higher-magnification images showing the faint presence of laminin $\alpha 2$ in fractone bulbs (arrowheads). C, Higher-magnification images depicting fractone stems, rich in laminin $\alpha 2$ emerging from a blood vessel and contacting fractone bulbs (arrowhead). $\boldsymbol{D}, \boldsymbol{E}$, Higher-magnification images showing the ubiquitous presence of laminin $\alpha 5$ in fractone bulbs $(\boldsymbol{D})$ and in its absence $(\boldsymbol{E})$ in most of the fractone stems. $\boldsymbol{F}$, Orthogonal views from a coronal section of a FoxJ1-RFP mouse showing that fractone bulbs are located at the ependymal layer only. Fractone bulbs may appear in thick stripes in coronal sections due the angle of the lateral wall and the thickness of the optical section. Asterisks indicate the ventricular cavity. Scale bars: $A, 100 \mu \mathrm{m} ; \boldsymbol{B}, \boldsymbol{D}, 50 \mu \mathrm{m} ; \boldsymbol{C}, \boldsymbol{E}, 50 \mu \mathrm{m}$; $F, 20 \mu \mathrm{m}$.

which abundant processes radiate out to make contact with surrounding individual bulbs (Fig. $1 D-F$ ). These bulbs are aligned with the apical pole of ependymal cells at the ventricular surface (Fig. 1G, surface, arrowheads, bottom insets). Most fractone bulbs occur at the basolateral side of the ependymal cells, where they contact $\mathrm{GFAP}^{+}$processes (Fig. 1G, 6.2 $\mu \mathrm{m}$ deep, arrowheads). Three-dimensional reconstruction and orthogonal views of contact points between $\mathrm{GFAP}^{+}$processes and bulbs at pinwheel centers (Fig. 1G, arrowheads 1-3) revealed direct contact between these two structures.

\section{Fractone bulbs are enriched in}

\section{laminin $\alpha$}

We used coronal sections of the SVZ and monoclonal antibodies specific for laminin $\alpha$ chains to investigate the laminin isoforms present in fractones. We found that fractone bulbs exhibited strong laminin $\alpha 5$ staining, and only very few contained the $\alpha 2$ chain (Fig. $2 A-E$ ). Laminin $\alpha 4$ was not found in any fractone bulb (Fig. $2 A$ ), in contrast to previous reports (Kazanis et al., 2010). Laminin $\alpha 1$ and $\alpha 3$ chains were also completely absent in bulbs (data not shown), which is consistent with the literature (Kazanis et al., 2010). Conversely, the predominant laminin $\alpha$ chain present in stems was laminin $\alpha 2$ (Fig. 2C,E), which, in the adult CNS, is produced mostly by astrocytes of the blood-brain barrier (Sixt et al., 2001) and potentially by pericytes (Armulik et al., 2010). Some staining for laminin $\alpha 4$ and $\alpha 5$ was found in stems (data not shown). Surprisingly, we found that although a few bulbs contacted stems (Fig. 2C,E, arrowheads) the vast majority did not touch stems, which together with the observation that they contain different laminin chains, suggests that bulbs and stems are independent structures.

To properly interpret the images in Figure 2, as well as in Figures 3 and 5, it is important to emphasize that the wall of the lateral ventricle is not always orthogonal to the coronal axis. As a consequence, the thicknesses of the stripes across which bulbs are seen vary largely between individual sections, despite bulbs being exclusively located between cells in the ependymal layer (Fig. 1C). This is verified with FoxJ1-RFP reporter mice that express RFP under the control of the ependymal-specific promoter FoxJ 1 (Fig. 2F).

\section{Fractone bulbs are produced by ependymal cells during the first week after birth}

To determine when fractone bulbs form and whether this correlates with the appearance of laminin $\alpha 5$ expression, we investigated the emergence of fractones at the ependymal walls during development. To do so, we checked the laminin expression at the SVZ every day during the first week after birth. Fractone bulbs, as defined by a punctate laminin staining, were not detected at postnatal day 0 (P0); however, in addition to blood vessel staining, a faint and disperse laminin $\gamma 1$ chain staining lining the ventricle was detectable at the nestin ${ }^{+}$layer of late radial glial cells/early NSCs (Fig. $3 A$ ). A similar pattern was observed for the expression of laminin $\alpha 5$, whereas no positivity was detected for laminin $\alpha 2$ or $\alpha 4$ (data not shown). Laminin $\alpha 5$ expression in blood vessels in the CNS starts approximately at the third week after birth (Sorokin et al., 
1997a). However, in situ hybridization showed that mRNA for the laminin $\alpha 5$ chain is already expressed at the ventricle surface (Fig. 3B, arrow) and also at the choroid plexus at P0 (Fig. 3B, arrowhead) as reported previously (Sorokin et al., 1997a). At P3, more condensed spots positive for laminin $\gamma 1$ and $\alpha 5$ were present in some regions of the ventricle (Fig. 3C). Laminin expression was spatially heterogeneous, with dense laminin expression at regions of the dorsal wall while most portions of the lateral wall lacked laminin immunoreactivity. At P7, early laminin $\gamma 1^{+}$ (Fig. 3D) and $\alpha 5^{+}$(data not shown) fractones were visible along all the ependymal surfaces of the lateral ventricles. In a frontal view of a P7 ependyma using a wholemount preparation, we observed that these first fractones are small patches of BM (Fig. $3 E)$ not aligned with regions of cell-cell contact, as in adult mice (Fig. 1C). Curiously, these early deposits are seen only at the apical surface of the ependymal cells (Fig. $3 F$ ). Analysis of FoxJ1-RFP reporter animals revealed laminin $\gamma 1$ inside ependymal cells and some early fractones already at the cell surface (Fig. 3G).

The fact that fractone bulbs first appear as small BM patches at the apical surface of ependymal cells indicates that these structures undergo major spatial and morphological changes until adulthood. We therefore investigated whether fractone size changed over time by measuring their volumes in 3D stacks from confocal microscopy at P34, P86, P162, P175, P269, and P303. We observed that the mean volume increases gradually, showing a linear correlation with age $\left(R^{2}=0.91\right)$. This result extends the recent observation that bulbs are larger in 100-week-old mice than in 12-week-old mice (Kerever et al., 2015). A frequency distribution analysis showed that this increase in size occurs in the entire fractone population (Fig. $4 A, B$ ). Mice $>200 \mathrm{~d}$ of age displayed large fractone bulbs $\left(>40 \mu \mathrm{m}^{3}\right)$ and were associated with more $\mathrm{GFAP}^{+}$process contacts than bulbs in younger animals. Old mice ( $>200 \mathrm{~d}$ of age) displayed fractones with a tunnel-like structure whose lumens are occupied by neural stem cell processes (Fig. 4C). Tunneled bulbs, not seen in younger animals, were often, but not always, located at the center of pinwheels (Fig. 4C). In addition, old mice had unique enlarged fractone bulbs, with some reaching $>20 \mu \mathrm{m}$ in diameter (Fig. $4 D$, arrowheads). These giant fractones were associated with clusters of cells at the anterior ventral part of the ventricular wall (Fig. 4D, arrows). Such cell clusters were associated with both $\mathrm{GFAP}^{+}$and $\mathrm{GFAP}^{-}$cells, and were surrounded by a strong $\beta$-catenin expression (Fig. $4 E$, middle, red). We also observed fragmented laminin deposits in their interior (Fig. $4 E$, arrowheads). Serial imaging through the giant pinwheels and $3 \mathrm{D}$ reconstruction revealed that the giant bulbs associated with these clusters were filled with
$\mathrm{GFAP}^{+}$processes that traversed them and reached more distant and smaller fractones (Fig. $4 F$, top, bottom). These data indicate that fractones are not static structures, since their size, shape, position, and cellular interactions change gradually with age, becoming larger and more complex in old mice.

The early appearance of laminin $\alpha 5$ in fractone bulbs before its expression occurs at CNS blood vessels (Sorokin et al., 1997a) suggests an ependymal source of laminin $\alpha 5^{+}$fractones. To more precisely investigate this possibility, we investigated laminin $\alpha 5^{+}$ fractone bulbs in transgenic mice lacking the expression of Lama 5 in endothelium (Tek-Cre::Lama ${ }^{-l^{-}}$) and in ciliated epithelial cells including ependymal cells (FoxJ1-Cre::Lama5 ${ }^{-1-}$ ). Tek-Cre::Lama5 ${ }^{-1-}$ mice showed no changes in laminin $\alpha 5$ staining of fractone bulbs (Fig. 5A). We quantified the volumes of bulbs in $3 \mathrm{D}$ reconstructions of confocal stacks, and we did not 


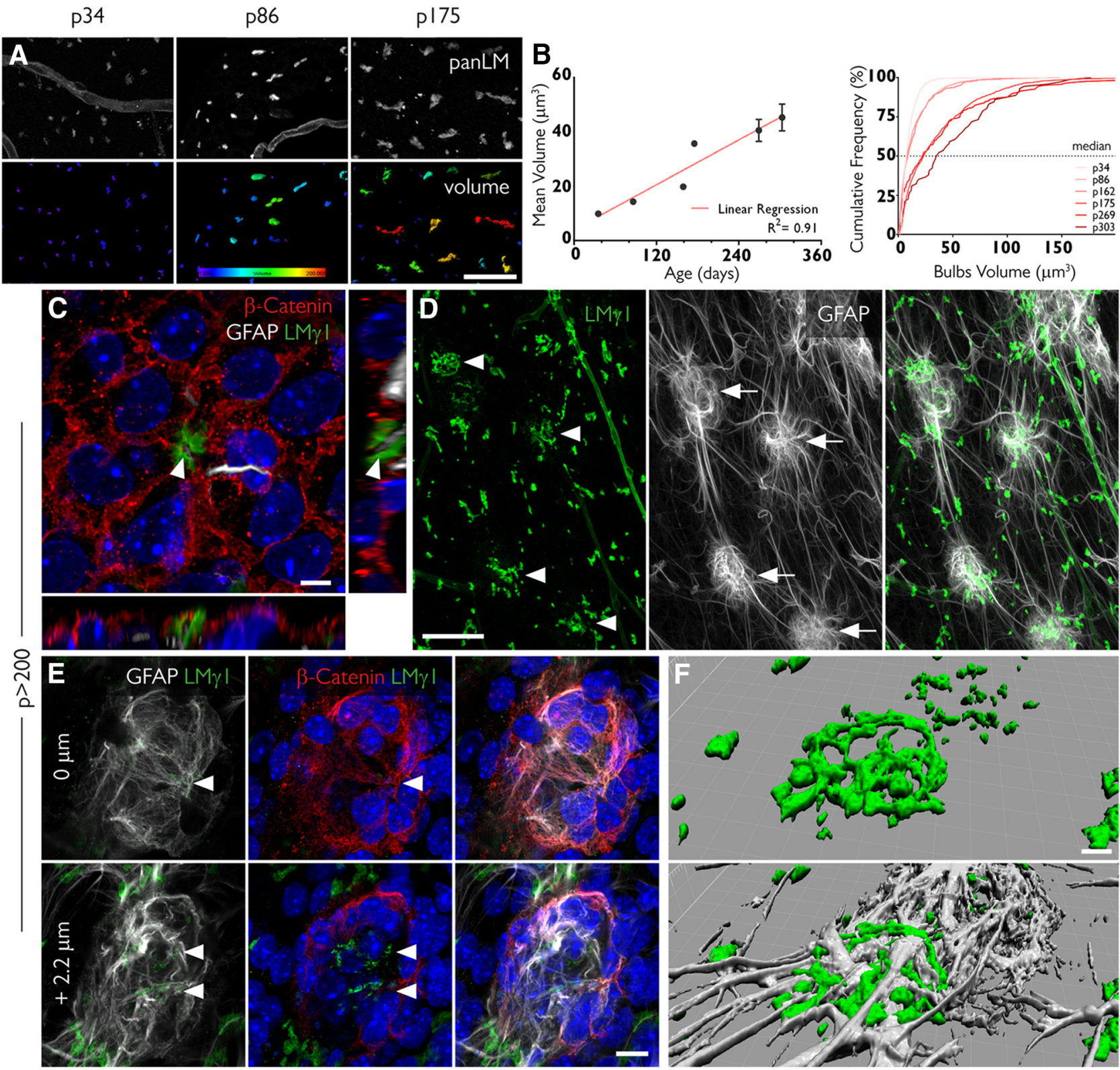

Figure 4. Fractones undergo major transformations with aging. $A$, Fractone bulbs, identified by immunofluorescent staining using a pan-laminin antibody (panLM; top), at three different ages. The volume of each individual bulb is color coded, showing that these structures increase in size with age. $B$, The mean volumes of fractones correlate with age $\left(R^{2}=0.91\right.$; left). An analysis of frequency showing that the median value for the volume of fractones also increases with age. $C$, A pinwheel in a whole mount of an 8-month-old mouse showing a tunneled fractone bulb at its center. Orthogonal views show a GFAP ${ }^{+}$process (gray) sheathed by the fractone BM (green). D, Unusually large fractones (green, arrowheads) are associated with clusters of GFAP ${ }^{+}$cells (gray, arrows). $\boldsymbol{E}$, A detailed view of a cell cluster shows strong expression of $\beta$-catenin (red) in its margins and fractone fragments (arrowheads) in its interior. $\boldsymbol{F}$, A tridimensional reconstruction of a giant fractone associated with a cell cluster showing how GFAP ${ }^{+}$processes transverse these structures. Scale bars: $\boldsymbol{A}, 30 \mu \mathrm{m} ; \boldsymbol{C}, 5 \mu \mathrm{m} ; \boldsymbol{D}, 50 \mu \mathrm{m} ; \boldsymbol{E}, 10 \mu \mathrm{m} ; \boldsymbol{F}, 5 \mu \mathrm{m}$.

find any significant differences among these genotypes [wildtype (WT) mice, $31.11 \pm 7.21 \mu \mathrm{m}^{3}$; Tek-Cre::Lama5 ${ }^{-1-}$ mice, $29.22 \pm 16.1 \mu^{3}$; Fig. $\left.5 B\right]$, suggesting that endothelial cells are not the cellular source of fractone bulbs. However, FoxJ1-Cre:: Lama $5^{-1-}$ mice showed almost complete loss of laminin $\alpha 5$ staining at fractone bulbs by 1 month of age and only very few small laminin $\alpha 5^{+}$fractones (Fig. $5 \mathrm{C}$, left, arrowheads). The activation of FoxJ1 promoter is temporally and spatially heterogeneous, starting at $\mathrm{P} 0$ and continuing until the third week after birth (Jacquet et al., 2009). Therefore, the few laminin $\alpha 5$-containing bulbs persisting in 1-month-old mutants were probably produced before the deletion was triggered by the FoxJ1 activation. We next investigated whether laminin $\alpha 5$ containing bulbs were still present in FoxJ1-Cre::Lama5 $5^{-1-}$ mice at 2 months of age. We found no laminin $\alpha 5$ in fractone bulbs, although it was still present in association with endothelial BMs (Fig. 5D, center).

Despite the lack of laminin $\alpha 5$ in FoxJ1-Cre::Lama5 ${ }^{-1-}$ mice, fractone bulbs were still present, as indicated by positive staining for other laminin chains, such as laminin $\gamma 1$ (Fig. 5D) and $\beta 1$ chains, and the other BM components, such as collagen type IV and perlecan (data not shown). Moreover, there were no detectable alterations in the general architecture of the ependymal layer, as judged by $\beta$-catenin immunoreactivity (data not shown). Since laminins are heterotrimers, this finding suggests that other $\alpha$ chains could be expressed in fractones to compensate for the lack of laminin $\alpha 5$. Screening for the expression of the other laminin $\alpha$ chains revealed upregulation of laminin $\alpha 2$ at fractone bulbs of FoxJ1-Cre::La- 

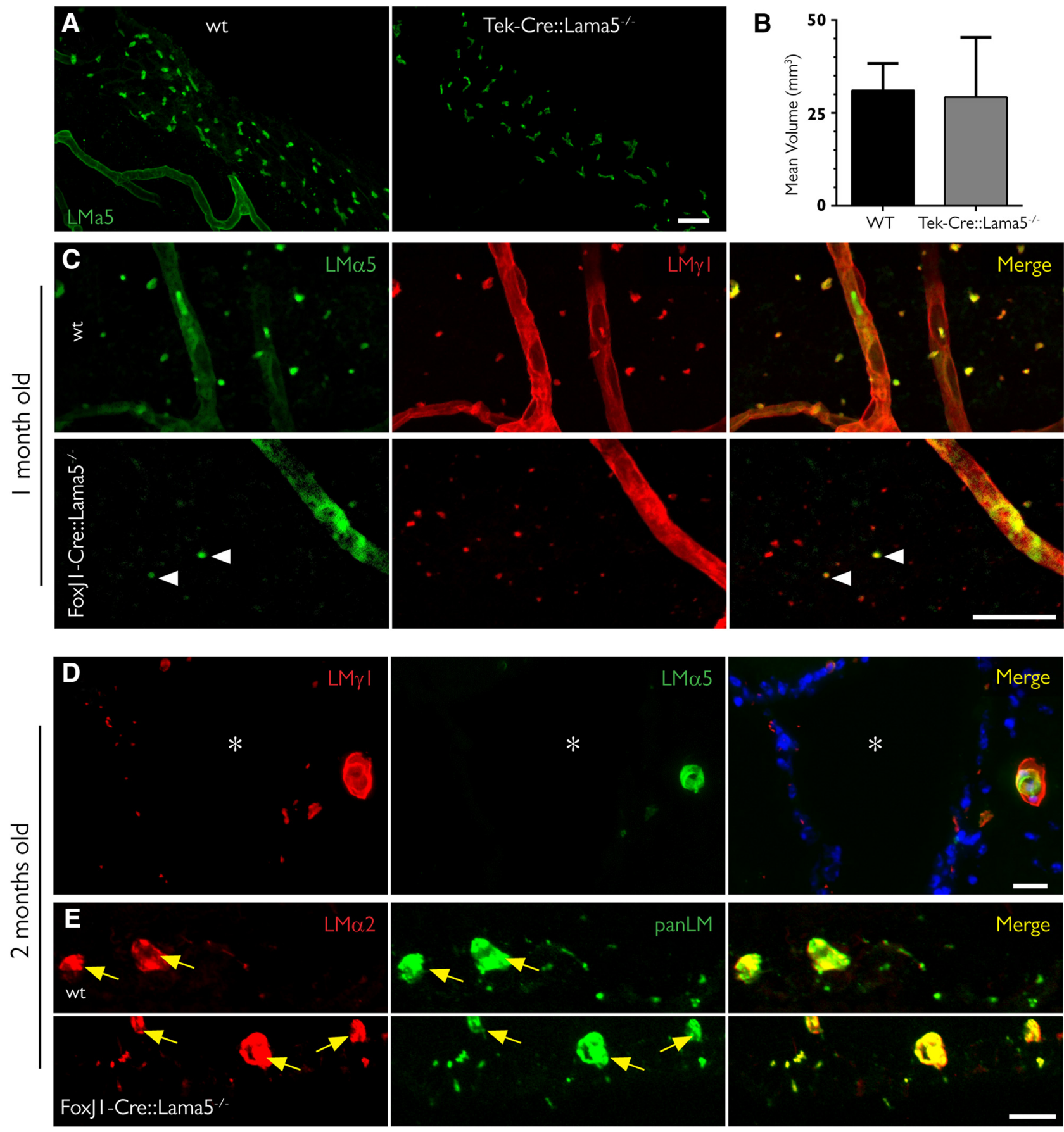

Figure 5. Deletion of the Lama5 gene in ependymal cells eliminates laminin $\alpha 5$ in fractones bulbs. $A$, Maximum intensity projection of 50 - $\mu \mathrm{m}$-thick coronal sections of 5 -month-old mice showing that the expression of laminin $\alpha 5$ (green) is not altered in mice lacking the Lama5 gene in endothelial cells (Tie2/Lama $5^{-1-}$ ), indicating that these cells are not the source of the laminin $\alpha 5$ found in fractones. $\boldsymbol{B}$, Analysis of the volume of fractones showing no difference in bulb size among these genotypes (data are the mean \pm SEM, $t$ test, $n=3$ ) $\boldsymbol{C}$, The vast majority of fractones in 1-month-old FoxJ1/Lama5 ${ }^{-1-}$ lack laminin $\alpha 5$, the main $\alpha$ chain in WT animals. D, E, Two-month-old FoxJ1/Lama5 ${ }^{-1-}$ mice have no laminin $\alpha 5$ in fractone bulbs; instead, there is a compensatory upregulation of laminin $\alpha 2$ in these structures $(\boldsymbol{D})$, with an immunoreactivity similar to that in the blood capillaries in the vicinity (yellow arrows; $\boldsymbol{E})$. Asterisks indicate the ventricular cavity. Scale bars: $\boldsymbol{A}, 25 \mu \mathrm{m} ; \boldsymbol{C}, 25 \mu \mathrm{m} ; \boldsymbol{D}, 20 \mu \mathrm{m} ; \boldsymbol{E}, 20 \mu \mathrm{m}$.

ma5 $5^{-1-}$ mice, which is almost absent at this site in WT animals (Fig. 5E).

FoxJ1-Cre: Lama5 $^{-/-}$mice exhibit fewer slow-cycling NSCs and increased cell proliferation in the SVZ

As laminin $\alpha 5$ has been shown to maintain embryonic stem cells in a nondifferentiated state and to regulate cell proliferation (Domogatskaya et al., 2008), we investigated whether the observed changes in laminin isoform expression in the FoxJ1-Cre::Lama5 $5^{-1-}$ mice could interfere with the physiology of the neural stem cell niche. We evaluated the number of NSCs in the SVZ by pulsing the thymidine analog EdU and tracking labeled cells after 6 weeks, using whole mounts of lateral wall preparations from WT and FoxJ1-Cre::Lama5 ${ }^{-1-}$ mice (Fig. 6A). In this setup, only slowly or nondividing cells retain high levels of EdU. We found a significant $18 \%$ reduction in the number of NSCs in FoxJ1-Cre:: Lama $^{-1-}$ mice compared with WT mice $\left(4.95 \pm 0.20 \times 10^{-8}\right.$ vs $4.04 \pm 0.27 \times 10^{-8}$ cells $/ \mu \mathrm{m}^{2}$, respectively; $p=0.02$; Fig. $\left.6 B\right)$. 
A

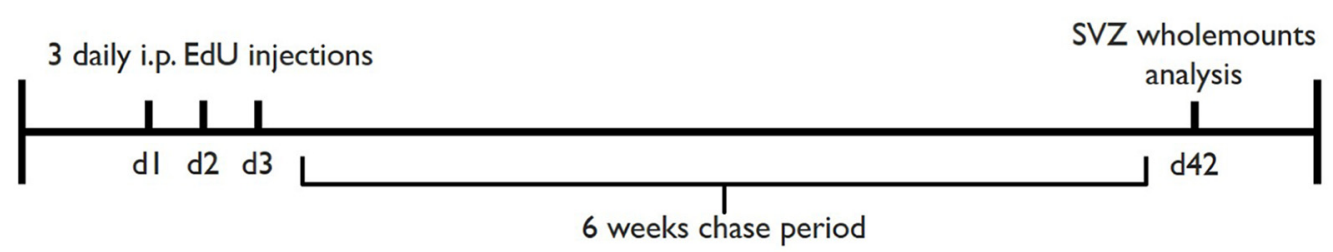

B
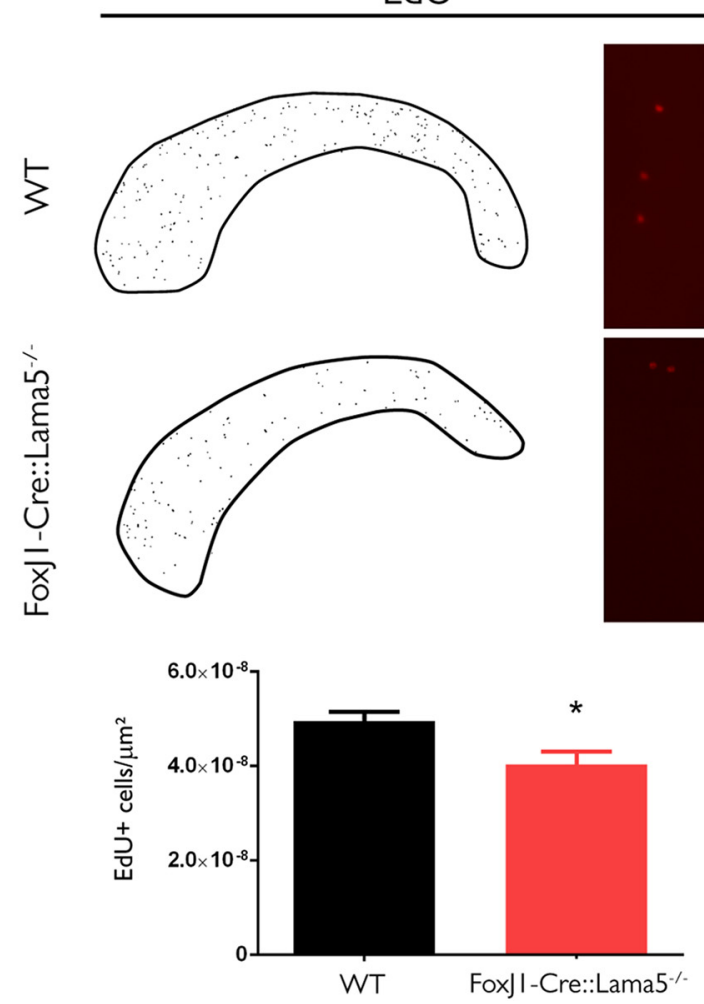

C
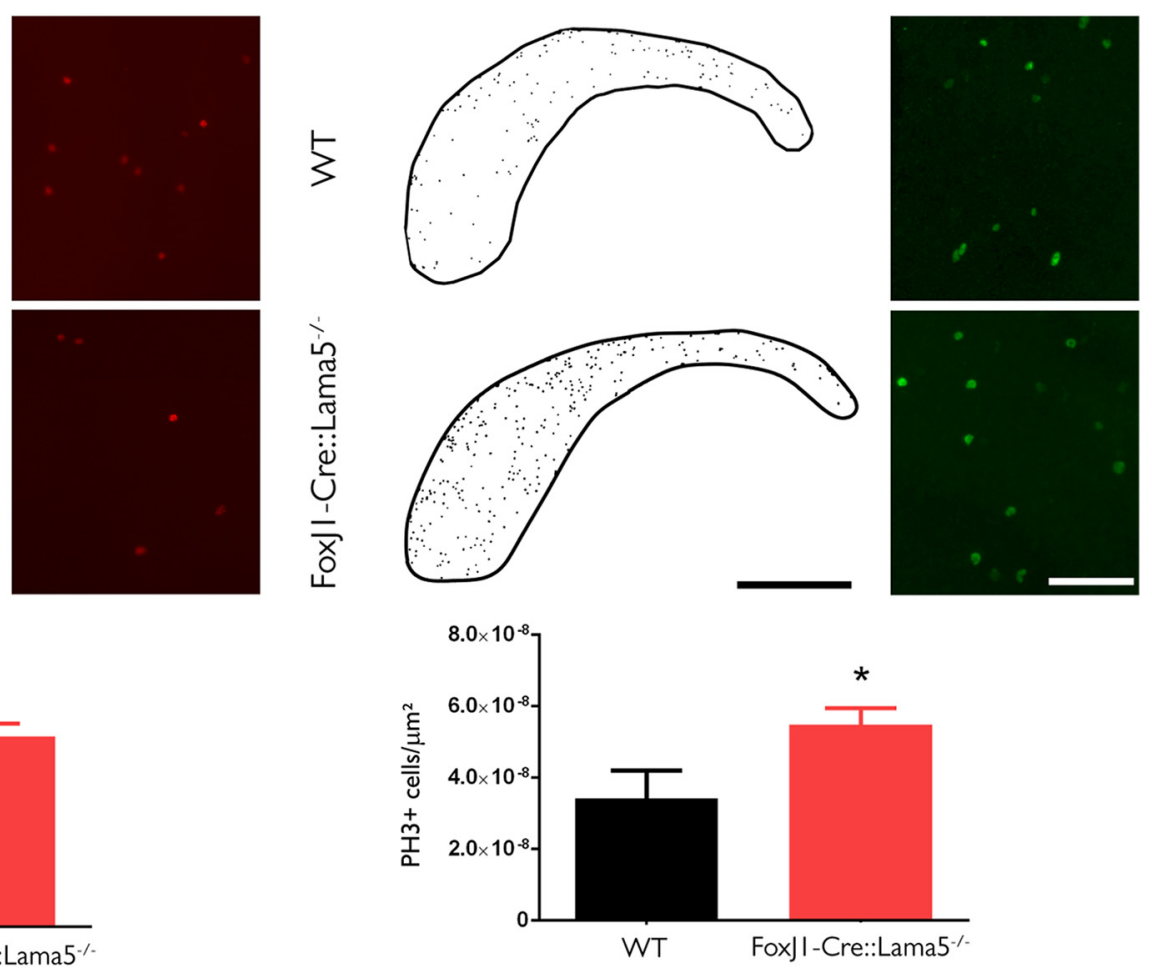

Figure 6. Laminin content of fractone bulbs affects NSPC behavior in the SVZ. A, EdU was administered to 3-month-old mice for $3 \mathrm{~d}$, and the following 6 weeks were a chase period. After that, SVZ whole mounts were analyzed using epifluorescence (to assess all cells possibly labeled from the ependymal layer at the ventricular surface down to the SVZ), and EdU-retaining cells and PH3 ${ }^{+}$ cells were counted. $\boldsymbol{B}$, Counting of label retaining cells in the lateral ventricle of WT and FoxJ1/Lama $5^{-/}$mice revealed a reduction in the number of quiescent neural stem cells [from $4.95 \pm$ $0.20 \times 10^{-8}$ cells $/ \mu \mathrm{m}^{2}(N=6)$ vs $4.04 \pm 0.27 \times 10^{-8}$ cells $\left./ \mu \mathrm{m}^{2}(N=8) ; p=0.02\right]$. C, Whole mounts were also immunofluorescently stained for PH3, a mitosis marker. FoxJ1/Lama5 $-1-$ animals have a significant increase in the number of dividing cells compared with WT animals $\geq 5.48 \pm 0.45 \times 10^{-8} \mathrm{cells}_{\mathrm{s}} / \mu \mathrm{m}^{2}(\mathrm{~N}=5) \mathrm{vs} 3.42 \pm 0.77 \times 10^{-8}$ cells $\left./ \mu \mathrm{m}^{2}(\mathrm{~N}=5) ; p=0.04\right]$. $N$ refers to individual whole mounts. Asterisks indicate significant differences between genotypes. Scale bars: $\boldsymbol{B}, \boldsymbol{C}$, low magnification, 1 mm; $\boldsymbol{B}, \boldsymbol{C}$, high magnification, $100 \mu \mathrm{m}$.

We also compared the total number of dividing cells in the SVZ, as assessed by $\mathrm{PH} 3$ staining, revealing a $60 \%$ increase in the number of dividing cells when laminin $\alpha 5$ was absent from the fractone bulbs $\left(3.42 \pm 0.77 \times 10^{-8}\right.$ vs $5.48 \pm 0.45 \times 10^{-8}$ cells $/ \mu \mathrm{m}^{2}$, respectively; $p=0.04$; Fig. $6 C$ ). These results indicate that the deletion of laminin $\alpha 5$ expression in ependymal cells reduces the quiescent stem cell pool, provoking an increase in the proliferation of progenitor cells.

\section{Discussion}

We demonstrate here that a major laminin component of the fractone bulbs in the SVZ is laminin $\alpha 5$-containing isoforms, which are produced by the ependymal cells, and that the laminin content of fractones affects cell division in the SVZ. We additionally show that bulbs and stems, the two components of fractones, may represent independent structures, since they have distinct ECM compositions and are not always connected.

Fractones have been described as complex structures that emerge as branching lines from the BMs of blood vessels in the vicinity of the SVZ and terminate as bulbs at the ventricular surface. Given their expression of laminin $\alpha 5$, which is expressed in the CNS mainly by endothelial cells and is deposited into the endothelial BM (Sorokin et al., 1997a; Sixt et al., 2001), it was logical to postulate endothelial cells as the source of fractones (Shen et al., 2008). However, in addition to endothelium, laminin $\alpha 5$ is one of the major BM components of epithelial cells (Sorokin et al., 1997a,b) and has been previously described to be expressed by choroid plexus epithelium (Sorokin et al., 1997a). The use of transgenic mice lacking laminin $\alpha 5$ from either endothelial or ependymal cells revealed that the main source of laminin $\alpha 5$, and presumably also fractone bulbs, is the ependymal cells lining the ventricle. We show here that fractone bulbs are in the ependymal cell layer, often in the center of pinwheels at the interface between neural stem cells and CSF. Our data also indicate that these interactions are dynamic, since fractone bulbs increase in size and their association with the $\mathrm{GFAP}^{+}$neural stem cells increases in complexity with age. 
Our data also showed that the elimination of laminin $\alpha 5$ from ependymal cells increased overall cell proliferation in the SVZ and reduced the number of slow-dividing neural stem cells. After NSC activation and division, its progeny leave the SVZ within $\sim 4-5 \mathrm{~d}$ (Ponti et al., 2013). Since the chase period used here was 6 weeks, cells retaining EdU in the SVZ correspond to the small fraction of quiescent NSCs undergoing division within the $3 \mathrm{~d}$ period of the EdU pulse. Hence, those cells that were reduced by $18 \%$ are probably quiescent NSCs (inactive B cells) that were likely activated and started cycling faster in the absence of laminin $\alpha 5$. A possible explanation for the laminin $\alpha 5$-mediated maintenance of NSC quiescence could be through an indirect effect on TGF- $\beta$ signaling. Although it is not clear how, it has been shown that the laminin $\alpha 5$-containing isoform laminin-511 strongly enhances TGF- $\beta$ signaling in epidermal stem cells (Morgner et al., 2015). TGF- $\beta$ is an important factor that promotes quiescence in adult neural stem cells, and its expression correlates with proliferation inhibition in the hippocampus (Kandasamy et al., 2014). The concomitant $60 \%$ increase in total cell proliferation in the SVZ in FoxJ1-Cre::Lama5 ${ }^{-1-}$ mice is consistent with this hypothesis. However, we cannot exclude that the lack of laminin $\alpha 5$ induces two separate effects, inhibiting the activation of B cells and independently stimulating the proliferation of neural progenitors. Nevertheless, our results suggest a role for laminin $\alpha 5$-containing fractone bulbs in the maintenance of the slowdividing neural stem cell pool. Further studies using specific markers of quiescent and activated NSCs and transit-amplifying cells will be necessary to determine precisely how laminin $\alpha 5$ affects the dynamics of cell division within the neural stem cell niche.

Loss of laminin $\alpha 5$ correlated with a broader expression of laminin $\alpha 2$ in fractones. While the current data do not permit a distinction between an antiproliferative effect of laminin $\alpha 5$ or a proproliferative effect of laminin $\alpha 2$, the former is consistent with data from other tissues, suggesting that laminin $\alpha 5$ is a central factor in other stem cell niches. Stem cell niches in epithelia, bone marrow, and the vascular niche in the hippocampus, are all rich in laminin $\alpha 5$ (Miner et al., 1997; Palmer et al., 2000; Kiel et al., 2005). Selective deletion of laminin $\alpha 5$ from keratinocytes has recently been shown to provoke hyperproliferation of cells in the basal layer of epidermis (Wegner et al., 2016). Laminin $\alpha 5$ containing isoforms also inhibit differentiation of embryonic stem cells, maintaining them in an antiproliferative early progenitory state, through integrin signaling (Domogatskaya et al., 2008; Rodin et al., 2010; Hongisto et al., 2012). Consistent with an effect of laminin $\alpha 5$ on the maintenance of neural stem cell quiescence, laminin receptors integrin $\alpha 6 \beta 1$, which has a higher affinity for laminin $\alpha 5$ compared with laminin $\alpha 2$-containing isoforms (Nishiuchi et al., 2006), and $\alpha$-dystroglycan are also associated with fractones (Shen et al., 2008; Adorjan and Kalman, 2009) and are downregulated on neural stem cells upon activation (Codega et al., 2014). The delivery of antibodies against this integrin into the CSF leads to a loss of NSC anchorage and increases its proliferation in $50 \%$ of NSCs (Shen et al., 2008) and to the proliferation of undifferentiated Sox ${ }^{2+}$ cells in $40 \%$ of NSCs (Kazanis et al., 2010). However, it was assumed that the endothelial BM was the only source of ligands for the integrin $\alpha 6 \beta 1$, even though it is not clear whether stem cell processes directly contact laminin $\alpha 5$ in the endothelial BM.

As part of the blood-brain barrier, astrocytes ensheath capillaries in the CNS and produce a parenchymal BM rich in laminin $\alpha 2$, concealing the endothelial BM from other cells in the brain parenchyma (Sixt et al., 2001). It is not clear whether neural stem cells, due to their astrocytic phenotype, contribute to this parenchymal BM in the SVZ. In either scenario, the endothelial BM would not be fully available to integrin binding by NSC. In addition, we show here that stem cells can establish far more contacts with fractones than with blood vessels, hence, most of the exposed ligand for integrin $\alpha 6 \beta 1$ in NSCs is the laminin $\alpha 5$ in fractone bulbs. We therefore propose that the integrin $\alpha 6 \beta 1^{+}$ neural stem cells interact with laminin $\alpha 5$ in fractones, which maintains neural stem cell character and limits proliferation and differentiation.

We also showed that pinwheels, formed by adjacent ependymal cells, can accommodate fractone bulbs at their centers where neural stem cell processes contact the CSF. We presume that these fractones provide an adherence spot for ependymal cell bodies and the apical processes of neural stem cells. In addition, the pinwheel center is a privileged site for tuning stem cell behavior, since the primary cilia at the tip of the apical process works as a signaling hub (Ihrie and Alvarez-Buylla, 2011). Having a BM at this critical site may help to stabilize the apical process in contact with the ventricle, exposing it to growth factors accumulated in fractones and enabling molecules at very low concentrations in the CSF to regulate neurogenesis. This interaction between apical processes and fractones increases in complexity during aging, as tunneled bulbs fully wrap the apical ending of stem cells. We also observed an increase in the size of fractone bulbs with increased age of mice, confirming and extending recent findings that described a reduction in fractone bulb numbers with age (Kerever et al., 2015). The observed correlation between enlarged bulbs and $\mathrm{GFAP}^{+}$cells clusters, which indicates that $\mathrm{GFAP}^{+}$cells could participate in the merging of these structures, may result in the reduced fractone number reported by Kerever et al. (2015). Together with our findings, which suggest an effect of laminin $\alpha 5$ in maintaining stem cell quiescence, the fusion of fractone bulbs could account for the age-related increase in neural stem cell activation, stem cell depletion, and decline of neurogenesis (Shook et al., 2012).

In summary, our work shows that laminin $\alpha 5$-containing fractones are a critical element in the SVZ niche, being part of pinwheels and modulating cell proliferation. Our data suggest that laminin $\alpha 5$ in fractones acts as a key stem cell niche factor. Further analyses of FoxJ1-Cre::Lama $5^{-1-}$ mice, investigating in detail the activation states of neural stem cells and the changes in NSPC populations will aid in understanding the exact role of laminin $\alpha 5$ in fractones.

\section{References}

Adorjan I, Kalman M (2009) Distribution of beta-dystroglycan immunopositive globules in the subventricular zone of rat brain. Glia 57:657-666. CrossRef Medline

Armulik A, Genové G, Mäe M, Nisancioglu MH, Wallgard E, Niaudet C, He L, Norlin J, Lindblom P, Strittmatter K, Johansson BR, Betsholtz C (2010) Pericytes regulate the blood-brain barrier. Nature 468:557-561. CrossRef Medline

Codega P, Silva-Vargas V, Paul A, Maldonado-Soto AR, DeLeo AM, Pastrana E, Doetsch F (2014) Prospective identification and purification of quiescent adult neural stem cells from their in vivo niche. Neuron 82:545559. CrossRef Medline

Colognato H, Yurchenco PD (2000) Form and function: the laminin family of heterotrimers. Dev Dyn 218:213-234. CrossRef Medline

Doetsch F, Caillé I, Lim DA, García-Verdugo JM, Alvarez-Buylla A (1999) Subventricular zone astrocytes are neural stem cells in the adult mammalian brain. Cell 97:703-716. CrossRef Medline

Domogatskaya A, Rodin S, Boutaud A, Tryggvason K (2008) Laminin-511 but not $-332,-111$, or -411 enables mouse embryonic stem cell selfrenewal in vitro. Stem Cells 26:2800-2809. CrossRef Medline

Douet V, Arikawa-Hirasawa E, Mercier F, Eri A-H, Mercier F, Arikawa-Hirasawa 
E, Mercier F (2012) Fractone-heparan sulfates mediate BMP-7 inhibition of cell proliferation in the adult subventricular zone. Neurosci Lett 528:120 125. CrossRef Medline

Durbeej M (2010) Laminins. Cell Tissue Res 339:259-268. CrossRef Medline

Hongisto H, Vuoristo S, Mikhailova A, Suuronen R, Virtanen I, Otonkoski T, Skottman H (2012) Laminin-511 expression is associated with the functionality of feeder cells in human embryonic stem cell culture. Stem Cell Res 8:97-108. CrossRef Medline

Ihrie RA, Alvarez-Buylla A (2011) Lake-front property: a unique germinal niche by the lateral ventricles of the adult brain. Neuron 70:674-686. CrossRef Medline

Jacquet BV, Salinas-Mondragon R, Liang H, Therit B, Buie JD, Dykstra M, Campbell K, Ostrowski LE, Brody SL, Ghashghaei HT (2009) FoxJ1dependent gene expression is required for differentiation of radial glia into ependymal cells and a subset of astrocytes in the postnatal brain. Development 136:4021-4031. CrossRef Medline

Kandasamy M, Lehner B, Kraus S, Sander PR, Marschallinger J, Rivera FJ, Trümbach D, Ueberham U, Reitsamer HA, Strauss O, Bogdahn U, Couillard-Despres S, Aigner L (2014) TGF-beta signalling in the adult neurogenic niche promotes stem cell quiescence as well as generation of new neurons. J Cell Mol Med 18:1444-1459. CrossRef Medline

Kazanis I, Lathia JD, Vadakkan TJ, Raborn E, Wan R, Mughal MR, Eckley DM, Sasaki T, Patton B, Mattson MP, Hirschi KK, Dickinson ME, ffrench-Constant C (2010) Quiescence and activation of stem and precursor cell populations in the subependymal zone of the mammalian brain are associated with distinct cellular and extracellular matrix signals. J Neurosci 30:9771-9781. CrossRef Medline

Kerever A, Mercier F, Nonaka R, de Vega S, Oda Y, Zalc B, Okada Y, Hattori N, Yamada Y, Arikawa-Hirasawa E (2014) Perlecan is required for FGF-2 signaling in the neural stem cell niche. Stem Cell Res 12:492-505. CrossRef Medline

Kerever A, Yamada T, Suzuki Y, Mercier F, Arikawa-Hirasawa E (2015) Fractone aging in the subventricular zone of the lateral ventricle. J Chem Neuroanat 66-67:52-60. CrossRef Medline

Kiel MJ, Yilmaz OH, Iwashita T, Yilmaz OH, Terhorst C, Morrison SJ (2005) SLAM family receptors distinguish hematopoietic stem and progenitor cells and reveal endothelial niches for stem cells. Cell 121:1109-1121. CrossRef Medline

Laperle A, Hsiao C, Lampe M, Mortier J, Saha K, Palecek SP, Masters KS (2015) $\alpha$-5 laminin synthesized by human pluripotent stem cells promotes self-renewal. Stem Cell Rep 5:195-206. CrossRef

Leonhardt H, Desaga U (1975) Recent observations on ependyma and subependymal basement membranes. Acta Neurochir (Wien) 31:153-159. CrossRef

Mercier F, Douet V (2014) Bone morphogenetic protein-4 inhibits adult neurogenesis and is regulated by fractone-associated heparan sulfates in the subventricular zone. J Chem Neuroanat 57-58:54-61. CrossRef Medline

Mercier F, Kitasako JT, Hatton GI (2002) Anatomy of the brain neurogenic zones revisited: fractones and the fibroblast/macrophage network. J Comp Neurol 451:170-188. CrossRef Medline

Mercier F, Schnack J, Saint M, Chaumet G (2011) Neurogenesis in the adult brain I (Seki T, Sawamoto K, Parent JM, Alvarez-Buylla A, eds). Tokyo: Springer Japan.

Mercier F, Kwon YC, Douet V (2012) Hippocampus/amygdala alterations, loss of heparan sulfates, fractones and ventricle wall reduction in adult BTBR T + tf/J mice, animal model for autism. Neurosci Lett 506:208-213. CrossRef Medline

Miner JH, Patton BL, Lentz SI, Gilbert DJ, Snider WD, Jenkins NA, Copeland NG, Sanes JR (1997) The laminin $\alpha$ chains: expression, developmental transitions, and chromosomal locations of $\alpha 1-5$, identification of heterotrimeric laminins $8-11$, and cloning of a novel $\alpha 3$ isoform. J Cell Biol 137:685-701. CrossRef Medline

Mirzadeh Z, Merkle FT, Soriano-Navarro M, Garcia-Verdugo JM, AlvarezBuylla A (2008) Neural stem cells confer unique pinwheel architecture to the ventricular surface in neurogenic regions of the adult brain. Cell Stem Cell 3:265-278. CrossRef Medline

Mirzadeh Z, Doetsch F, Sawamoto K, Wichterle H, Alvarez-Buylla A (2010) The subventricular zone en-face: wholemount staining and ependymal flow. J Vis Exp (39):e1938. CrossRef Medline

Miyazaki T, Futaki S, Suemori H, Taniguchi Y, Yamada M, Kawasaki M,
Hayashi M, Kumagai H, Nakatsuji N, Sekiguchi K, Kawase E (2012) Laminin E8 fragments support efficient adhesion and expansion of dissociated human pluripotent stem cells. Nat Commun 3:1236. CrossRef Medline

Morgner J, Ghatak S, Jakobi T, Dieterich C, Aumailley M, Wickström SA (2015) Integrin-linked kinase regulates the niche of quiescent epidermal stem cells. Nat Commun 6:8198. CrossRef Medline

Nishiuchi R, Takagi J, Hayashi M, Ido H, Yagi Y, Sanzen N, Tsuji T, Yamada M, Sekiguchi K (2006) Ligand-binding specificities of laminin-binding integrins: a comprehensive survey of laminin-integrin interactions using recombinant alpha3beta1, alpha6beta1, alpha7beta 1 and alpha6beta4 integrins. Matrix Biol 25:189-197. CrossRef Medline

Palmer TD, Willhoite AR, Gage FH (2000) Vascular niche for adult hippocampal neurogenesis. J Comp Neurol 425:479-494. CrossRef Medline

Ponti G, Obernier K, Guinto C, Jose L, Bonfanti L, Alvarez-Buylla A (2013) Cell cycle and lineage progression of neural progenitors in the ventricularsubventricular zones of adult mice. Proc Natl Acad Sci U S A 110:E1045E1054. CrossRef Medline

Rodin S, Domogatskaya A, Ström S, Hansson EM, Chien KR, Inzunza J, Hovatta O, Tryggvason K (2010) Long-term self-renewal of human pluripotent stem cells on human recombinant laminin-511. Nat Biotechnol 28:611-615. CrossRef Medline

Schuler F, Sorokin LM (1995) Expression of laminin isoforms in mouse myogenic cells in vitro and in vivo. J Cell Sci 108:3795-3805. Medline

Shen Q, Wang Y, Kokovay E, Lin G, Chuang SM, Goderie SK, Roysam B, Temple S (2008) Adult SVZ stem cells lie in a vascular niche: a quantitative analysis of niche cell-cell interactions. Cell Stem Cell 3:289-300. CrossRef Medline

Shook BA, Manz DH, Peters JJ, Kang S, Conover JC (2012) Spatiotemporal changes to the subventricular zone stem cell pool through aging. J Neurosci 32:6947-6956. CrossRef Medline

Sixt M, Engelhardt B, Pausch F, Hallmann R, Wendler O, Sorokin LM (2001) Endothelial cell laminin isoforms, laminins 8 and 10, play decisive roles in $\mathrm{T}$ cell recruitment across the blood-brain barrier in experimental autoimmune encephalomyelitis. J Cell Biol 153:933-946. CrossRef Medline

Smyth N, Vatansever HS, Murray P, Meyer M, Frie C, Paulsson M, Edgar D (1999) Absence of basement membranes after targeting the LAMC1 gene results in embryonic lethality due to failure of endoderm differentiation. J Cell Biol 144:151-160. CrossRef Medline

Song J, Lokmic Z, Lämmermann T, Rolf J, Wu C, Zhang X, Hallmann R, Hannocks MJ, Horn N, Ruegg MA, Sonnenberg A, Georges-Labouesse E, Winkler TH, Kearney JF, Cardell S, Sorokin L (2013) Extracellular matrix of secondary lymphoid organs impacts on B-cell fate and survival. Proc Natl Acad Sci U S A 110:E2915-E2924. CrossRef Medline

Sorokin L, Sonnenberg A, Aumailley M, Timpl R, Ekblom P (1990) Recognition of the laminin E8 cell-binding site by an integrin possessing the alpha 6 subunit is essential for epithelial polarization in developing kidney tubules. J Cell Biol 111:1265-1273. CrossRef Medline

Sorokin LM, Pausch F, Frieser M, Kröger S, Ohage E, Deutzmann R (1997a) Developmental regulation of the laminin alpha5 chain suggests a role in epithelial and endothelial cell maturation. Dev Biol 189:285-300. CrossRef Medline

Sorokin LM, Pausch F, Durbeej M, Ekblom P (1997b) Differential expression of five laminin alpha (1-5) chains in developing and adult mouse kidney. Dev Dyn 210:446-462. CrossRef Medline

Tavazoie M, Van der Veken L, Silva-Vargas V, Louissaint M, Colonna L, Zaidi B, Garcia-Verdugo JM, Doetsch F (2008) A specialized vascular niche for adult neural stem cells. Cell Stem Cell 3:279-288. CrossRef Medline

Wegner J, Loser K, Apsite G, Nischt R, Eckes B, Krieg T, Werner S, Sorokin L (2016) Laminin $\alpha 5$ in the keratinocyte basement membrane is required for epidermal-dermal intercommunication. Matrix Biol 56:24-41. CrossRef Medline

Wu C, Ivars F, Anderson P, Hallmann R, Vestweber D, Nilsson P, Robenek H, Tryggvason K, Song J, Korpos E, Loser K, Beissert S, Georges-Labouesse E, Sorokin LM (2009) Endothelial basement membrane laminin alpha5 selectively inhibits T lymphocyte extravasation into the brain. Nat Med 15:519-527. CrossRef Medline

Zhang Y, Huang G, Shornick LP, Roswit WT, Shipley JM, Brody SL, Holtzman MJ (2007) A transgenic FOXJ1-cre system for gene inactivation in ciliated epithelial cells. Am J Respir Cell Mol Biol 36:515-519. CrossRef Medline 